\title{
Booking.com Issue for Small Businesses in Turkey ${ }^{1}$
}

\author{
Arzu KILIÇLAR ${ }^{\text {a }}$ Fulden N. KÜÇÜKERGIN ${ }^{\text {iD }}$ Esin AYSEN ${ }^{\text {iD }}$ c K. Gürkan KÜÇÜKERGİN \\ a Ankara Haci Bayram Veli University, Faculty of Tourism, Department of Travel Management and Tour Guiding, Ankara, Turkey. \\ arzu.kiliclar@hbv.edu.tr \\ b Ankara Haci Bayram Veli University, Faculty of Tourism, Department of Travel Management and Tour Guiding, Ankara, Turkey. \\ fulden.kucukergin@hbv.edu.tr \\ c Ankara Haci Bayram Veli University, Faculty of Tourism, Department of Travel Management and Tour Guiding, Ankara, Turkey. \\ esin.aysen@hbv.edu.tr \\ d Atilim University, School of Business Administration, Ankara, Turkey.gurkan.kucukergin@atilim.edu.tr
}

\begin{tabular}{|c|c|}
\hline ARTICLE INFO & ABSTRACT \\
\hline $\begin{array}{l}\text { Keywords: } \\
\text { Small Businesses } \\
\text { Booking.com } \\
\text { Çeşme } \\
\text { Alaçati }\end{array}$ & $\begin{array}{l}\text { Purpose - Established in Amsterdam in 1996, Booking.com has become one of the world's largest } \\
\text { travel e-commerce companies from a small Dutch venture. Booking.com offers its users access to } \\
\text { many accommodation facilities around the world. In this respect, the small accommodation facilities } \\
\text { in many parts of the world which registered to the booking.com system and have the opportunity } \\
\text { to reach the consumer on the other side of the world. }\end{array}$ \\
\hline $\begin{array}{l}\text { Received } 25 \text { November } 2019 \\
\text { Revised } 23 \text { January } 2020 \\
\text { Accepted } 7 \text { February } 2020\end{array}$ & $\begin{array}{l}\text { Design/methodology/approach - Çeşme is a small province of İzmir, which is famous for its } \\
\text { windsurf center, lodgings, and boutique hotels. These small hotels give services with few rooms in } \\
\text { a warm atmosphere. Remarkably most of the owner/business exploiter of these small hotels does } \\
\text { the most of the work of his/her hotels. Moreover, also they are the travel agency of themselves and } \\
\text { had been using Booking.com. }\end{array}$ \\
\hline \multirow[t]{2}{*}{$\begin{array}{l}\text { Article Classification: } \\
\text { Research Article }\end{array}$} & $\begin{array}{l}\text { Findings - However, it was restricted to use Booking.com in domestic reservations on } 30 \text { March } \\
2017 \text { in Turkey. Due to the restriction of Booking.com in Turkey, many small businesses have been } \\
\text { adversely affected by this situation. This restriction has put these businesses into trouble in terms of } \\
\text { marketing, especially since the service providers that are equivalent to the services provided by } \\
\text { Booking.com are not fully efficient at that time. }\end{array}$ \\
\hline & $\begin{array}{l}\text { Discussion - This study aims to reveal the effects of booking.com restriction in Turkey, } \\
\text { Çeşme/Alaçatı via interview method. In this study, it was interviewed with } 12 \text { hotel owner/business } \\
\text { exploiter in Çeşme/Alaçatı in } 2017 \text { and } 2018 \text { to reveal the problems of Booking.com's domestic } \\
\text { restriction. It has seen that Booking.com restriction has various adverse effects on small businesses } \\
\text { in Çeşme/Alaçatı. }\end{array}$ \\
\hline
\end{tabular}

\section{INTRODUCTION}

\section{1. What is Booking.com?}

Established in Amsterdam in 1996, Booking.com has become one of the world's largest travel e-commerce companies from a small Dutch venture. Booking.com, part of The Priceline Group (NASDAQ: PCLN), employs more than 17,000 people in 198 offices in 70 countries around the world. One of the missions of Booking.com is; encourage people to explore the world. On Booking.com, from around the world, travelers bring together with bed \& breakfasts run by families, apartments, holiday homes to 5-star luxury holiday villages, treehouses, and even the igloo Booking.com is supported by various local group companies around the world. The task of these supporting companies is to provide domestic support for Booking.com and, in some cases, to provide customer service (Booking.com-1, 2019). Supporting companies do not provide an online booking service. These are only for customer services and emergencies.

\footnotetext{
${ }^{1}$ This study was presented with the name of "Is Bookıng.com a Way of Advertising for Small Hotels? The Case of Çeşme" as an abstract study at the International Conference on Tourism, Travel, Leisure and Hospitality-Selçuk, in 2017. Önerilen Atıf/ Suggested Citation

Kılıçlar, A., Küçükergin, F.N., Aysen, E., Küçükergin, K.G. (2020). Booking.com Issue for Small Businesses in Turkey, Journal of Business Research-Turk, 12 (1), 314-320.
} 
A. Kılıçlar - F. N. Küçükergin - E. Aysen - K. G. Küçükergin 12/1 (2020) 314-320

Table 1. Number of worldwide customer services of Booking.com

\begin{tabular}{|c|c|c|c|c|c|c|c|c|}
\hline Area & Europe & Asia & $\begin{array}{c}\text { North } \\
\text { America }\end{array}$ & $\begin{array}{c}\text { Central } \\
\text { America\& } \\
\text { Caribbean }\end{array}$ & $\begin{array}{c}\text { South } \\
\text { America }\end{array}$ & $\begin{array}{c}\text { Middle } \\
\text { East }\end{array}$ & Africa & Oceania \\
\hline Number & 32 & 14 & 3 & 4 & 5 & 6 & 5 & 2 \\
\hline
\end{tabular}

Ref. Booking.com-2, 2019

Europe: Netherlands, Austria, Belgium, Bulgaria, Croatia, Cyprus, Czech Republic, Denmark, Estonia, Finland, France, Germany, Georgia, Greece, Hungary, Iceland, Ireland, Italy, Latvia, Lithuania, Norway, Poland, Portugal, Romania, Russia, Slovakia, Slovenia, Spain, Sweden, Switzerland, United Kingdom, Ukraine.

Asia: Cambodia, China, Hong Kong, India, Indonesia, Japan, Malaysia, Philippines, Singapore, South Korea, Sri Lanka, Taiwan, Thailand, Vietnam.

North America: Canada, United States of America, Mexico.

Central America \& Caribbean: Costa Rica, Dominican Republic, Panama, Puerto Rico.

South America: Argentina, Brazil, Chile, Colombia, Peru.

Middle East: Egypt, Israel, Jordan, Saudi Arabia, Turkey, United Arab Emirates.

Africa: Ghana, Kenya, Morocco, Nigeria, South Africa.

Oceania: Australia, New Zealand.

With a total of 204 customer service offices in 70 countries around the world, supporting companies do not have the right to act as Booking.com transaction or service responsibilities.

Having such an extensive network, Booking.com is one of the largest travel distribution businesses in the world. Being a part of this massive business brings lots of opportunities to a small business. At this point, for small hotel management, only with a small payment, it is crucial to reach the other side of the world.

\section{2. Booking.com Restriction in Turkey}

In order to prevent unfair competition against union member travel agencies, the Turkish Travel Agents Association decided to suspend the online reservation portal 'Booking.com' in its activities in Turkey in March 2017 (Hürriyet, 2017; Sputniknews, 2017; Tekin Bilbil, 2019; Turizm Güncel, 2017). In the previous application of TÜRSAB to the Competition Authority, 'Booking.com' BV was fined 2 million 543 thousand 992,85 TL administrative penalty by "Competition Authority" due to the contrary actions of the competition (Fortune, 2017; Indigo Dergisi, 2017). Booking.com's restriction of the continuing case is still ongoing (Euronewstr, 2018; Sabah, 2018).

With this decision, Booking.com stopped domestic reservation transactions in Turkey. Booking.com users can make reservations through Turkey from other countries (Independent, 2017).

\section{2. 1. The Impact of the Internet to Tourism}

Porter's $(1979,1980)$ model of industry analysis lies upon the existence of Five Forces that collectively determine the profitability and intensity of competition in the industry. The emergence of the Internet affected all Five Forces as it changed the conditions of competition in the marketplace (Buhalis \& Zoge, 2007). The fact the use of the Internet has become especially widespread in recent years and has become the most widely used tool in information distribution systems.

Businesses in the tourism sector have begun to use this appropriate changeover system. The widespread use of developing technological opportunities by people and making shopping options on the internet attractive makes it possible for customers to make reservations and obtain information. 
Table 2. Benefits of internet

\begin{tabular}{|l|l|}
\hline & $\begin{array}{l}\text { o Equal access to information. } \\
\text { o Low-cost promotion and marketing. } \\
\text { o Cheaper in-house information sharing. } \\
\text { o Develop faster cooperation strategies. } \\
\text { o Faster and lower cost communication with customers. } \\
\text { o More sales with discounted sales policies. } \\
\text { o Low-cost product differentiation. } \\
\text { o Savings in exhibition attendance and prototype production for promotion. } \\
\text { o Reduction of bureaucracy with electronic payment and brochures. } \\
\text { o Much work in a short time, taking advantage of the speed of computer and information } \\
\text { networks. } \\
\text { o Ability to persuade customers with secure and continuous information }\end{array}$ \\
\hline o Get detailed information. \\
o Reduced dependence on mediation for information. \\
o Usage of personalized products. \\
o Compare alternatives. \\
o Individual direct booking and purchase.
\end{tabular}

Buhalis \& Main, 1998; Buhalis, 1999; Sarı, 2003.

The importance of the Internet for tourism has increased in recent years. Tourism as an information-intensive industry can gain essential synergies from the use of the Internet, but the internet also escalates competitive environments globally, and the market is reshaped due to a critical internet role in the tourism industry (Rehman et al., 2019).

Tourism has been a precursor in adopting and developing information and communication technology applications, and today, it is one of the best categories of products or services purchased over the Internet in Spain and other countries. (Munoz \& Amaral, 2009). Almost all developed nations use different ICT applications in order to facilitate international tourists and create synergies.

Understanding how travelers behave is critical to tourism businesses formulating appropriate marketing strategies to see the potential of the internet and social media entirely.

The fact that it is easily accessible and enables people to evaluate holiday options without effort makes the internet more effective (see Table 2). Many web sites promote tourism regions and provide all kinds of information.

As a tool of social media, Booking.com is an easy way to promote a business. According to the importance of social media usage purposes of businesses, to improve brand reputation, to benefit from marketing by mouth, to gain competitive advantage, to increase customer loyalty, to increase sales, to change business models (Cipriani, 2010). Online reputation is a significant and strategic factor in determining the competitiveness and marketing capacity of accommodation companies (Diaz \& Espino, 2018). For this reason, as a world-wide reservation system, booking.com has a critical mission to drive the information of small tourism businesses to faraway distances. 


\section{3. District of Çeşme}

Çeşme is at the intersection of Karaburun and Urla peninsula and the second most extreme point of Anatolia after the Bababurun Peninsula in the north. Chios Island in the west, Karaburun in the north and Urla in the east. Çeşme, which is only eight nautical miles away from Chios Island, has a coastal shrine that is ninety kilometers away, while it is eighty kilometers away from the center of Izmir. Today, there are 25 neighborhoods within the borders of the Cesme Municipality. As a result of strong trade relations between Anatolia and Chios Island, Çeşme has emerged as an industrial city and has developed into an agrarian city because the conditions of its surroundings have changed with time and have lost its function. Today, Çeşme is a city where intensive tourism activities are carried out, is also one of the preferred and well-known favorite destination area (Alkan, 2015; Gezgin, 2009; Gülderen, 2007).

Çeşme, one of the essential destinations of İzmir Province, Turkey's third-largest metropolitan city, has significant potentials in terms of natural, cultural, and physical values and developments and investments in the tourism sector. When the current urban structure, urban landscape and urbanization level of Çeşme are examined in general terms, it is evident that these two criteria are the effect of trade and agriculture functions, but the shaping effect of urban space and the most dominant function is tourism (Karaçöl \& Tunçoku, 2016).

Çeşme has 56 tourism investment certified and 48 tourism operation certified facilities, and there are also many accommodation facilities certified by a municipality which have 1.604 .958 overnight in 2016. Of these 48 hotels with tourism operation certification, 6 of them are 5-star, 5 of them are 4-star, 9 of them are 3-star, and 5 of them are 2-star. The other 22 hotels are small businesses. Most of these other accommodation facilities' type is municipality certified, small business/boutique hotel in Çeşme (İzmir İl Kültür Turizm Müdürlüğü, 1-2, 2017; Yatırım ve İşletmeler Genel Müdürlüğü, 2017).

\section{PURPOSE OF THE RESEARCH}

The purpose of this research is to show the effect of the domestic restriction of Booking.com on Çeşme tourism.

\section{1. Research Methodology}

This research is a qualitative study. In this context, observation and interview methods were used in the research process. For this reason, the data obtained in the research process is the primary data. Research questions were determined via literature review and discussions with expert academicians. As a result, eight questions were specified. The questions used in the research are as follows:

1. Is advertising important for a business? (If it is necessary, why, if it is not essential, why)?

2. Do you allocate a budget for the promotion of your business? How much annually, if you have a budget?

3. What methods do you use to promote your business?

4. Is there any public institution's contribution to the promotion of your business? What if, what are these?

5. Which reservation channels do you use in your business (Online / Agency Agreement)?

6. What do you think about the effect of online reservation systems to promotion? (Positive / negative) What is the impact on the promotion of your business?

7. How does Booking.com's restriction in Turkey affect your promotion and bookings? What are your efforts and initiatives to make up for the current situation?

8. What are your requests from public institutions and municipalities to support your publicity efforts?

\section{2. Findings}

The research was carried out using a fully structured interview form and snowball sampling method between the dates of 21.06.2017 and 26.07.2017 within five days with 12 hotel owner/business exploiter in Çeşme/Alaçatı. The interviews of the respondents, who accepted, were recorded. Descriptive analysis was used in the analysis of answers. 
A. Kılıçlar - F. N. Küçükergin - E. Aysen - K. G. Küçükergin 12/1 (2020) 314-320

Table 3. Participant information

\begin{tabular}{|c|c|c|c|}
\hline Participant & Type of business & Business age & Business location \\
\hline 1 & Lodging & 15 & Çeşme \\
\hline 2 & Boutique Hotel & 7 & Alaçatı \\
\hline 3 & Lodging & 10 & Çeşme \\
\hline 4 & Boutique Hotel & 2 & Alaçatı \\
\hline 5 & Boutique Hotel & 1 & Alaçatı \\
\hline 6 & Boutique Hotel & 3 & Alaçatı \\
\hline 7 & Boutique Hotel & 4 & Alaçatı \\
\hline 8 & Boutique Hotel & 8 & Çeşme \\
\hline 9 & Apart Hotel & 10 & Çeşme \\
\hline 10 & $2^{*}$ Hotel & 10 & Çeşme \\
\hline 11 & Boutique Hotel & 4 & Alaçatı \\
\hline 12 & Boutique Hotel & 6 & Alaçatı \\
\hline
\end{tabular}

Interviewers of 7 participants were from Alaçatı, and 5 were from Çeşme. Information on the responses of the participants to the questions is as follows:

1. Is advertising important for a business? (If it is necessary, why, if it is not essential, why)?

Participant 1:

"Advertising is essential for a business. Because advertising means business."

Participant 3:

"The advertising is essential. Because we need to make publicity so we can reach our potential customers."

Participant 4:

"Advertising increase awareness. This directly reflects the sales."

Apart from these, all the participants think advertising is essential for a business.

2. Do you allocate a budget for the promotion of your business? How much annually, if you have a budget?

9 businesses answered this question; "Yes, we have a large budget for advertising. Especially after the restriction of Booking.com, we have to find other ways of promotion." 3 businesses answered, "No, we do not have a budget for advertising. We trust word of mouth."

3. What methods do you use to promote your business?

All businesses use social media for advertising. For example, Booking.com, Instagram, Facebook accounts, Google ads, etc. Also, they have business cards, banners, and giving advertisements to local newspapers and magazines.

4. Is there any public institution's contribution to the promotion of your business? What if, what are these?

All 12 participants answered this question as "No, there is not any contributions from any public institution."

5. Which reservation channels do you use in your business (Online / Agency Agreement)?

All participants gave similar responses to this question. Agency agreements, various online announcements, and opportunity sites are the focus of responses. Moreover, restrictions on online bookings have caused an increase in walk-in customers.

6. What do you think about the effect of online reservation systems to promotion? (Positive / negative) What is the impact on the promotion of your business?

For example, it seems that the answers such as "We can reach many people far away with online reservation" (P1), "It provides us to reach a large target group" (P4). In tourism, it seems that a disadvantage related to the excess of distance between buyer and seller is eliminated at this point. Participants also reported that they uploaded the images/photos of the businesses and that they could present the visuals to potential customers 


\section{A. Kılıçlar - F. N. Küçükergin - E. Aysen - K. G. Küçükergin 12/1 (2020) 314-320}

as they wanted. This is an essential step in the realization of expectations in Oliver's (1997) satisfaction model in the customer mind.

7. How does Booking.com's restriction in Turkey affect your promotion and bookings? What are your efforts and initiatives to make up for the current situation?

This question is critical in reaching the purpose of the study. (P2)"... we are trying to manage with our previous customers" (P1), "...other online platforms are inadequate" (P6)" ... we have to work with 50 different platforms " (P5)," other booking systems have begun to get more commissions" (P7), and participants seem to have a common idea in this regard. All attendees are dissatisfied with this restriction. They look for compensation in other social media circles and various significant agencies. However, this means more cost to businesses.

8. What are your requests from public institutions and municipalities to support your publicity efforts?

There is an earnest expectation from the municipalities in this regard. They want from the municipality to develop practices that can make up for the lack of Booking.com.

In 2018 summer (between the dates 17-19 August), while the restriction of booking.com has been continuing, the same questions asked to the same hotel owners. 3 of 12 businesses were closed due to financial issues. Restriction of booking.com was still a problem for their businesses.

\section{CONCLUSION}

The survival of the tourism business is directly related to the intensity of its contacts with its customers. The regulations that will limit it arise as the problems to be overcome. Undoubtedly, businesses operating in an open environment may have to override their processes according to legal regulations (Kotler, Bowen, and Makens, 2003). However, the effect of some regulations that can force the existence of businesses. Domestic restriction of access to Booking.com in Turkey is such an example.

Moreover, as the non-traditional media are addressable, interactive, and response-measurable, as Schiffman, Kanuk, and Wisenblit (2010) point out, they are now also preferred and used by businesses at severe levels. Every arrangement in this area brings together various influences. Some regulations can reduce the effect of the advantages mentioned. This research sheds light on this issue.

This research, conducted with 12 hotel owner/business exploiter, revealed some precise results. These are, in fact, directly related to how small businesses are visible on the Internet and more important than that is which part they are.

Booking.com has reached a point such as "Google" for hotels. As can be seen from this research, potential customers can plan their vacations by reviewing many hotels from there. Business managers have been tempted to seek solutions in the short term. Especially for a region where the economy of the region is very tied to tourism, this effect is likely to affect other affiliated sectors as well.

Because it is a very legal decision more than an administrative decision, the enterprises must follow the legal process first. However, in the long term, associations and municipalities should carry out legislative work. Also, as one participant emphasizes, giving weight to various social media tools can be a short-term solution. Collective agreements to be made with alternatives may also benefit small businesses.

This research was mainly directed towards those who affected the booking.com restriction. The subject can be examined in more detail utilizing the studies to be carried out on the customers who are the stakeholders of the subject and the units that are satisfied with this process. This exploratory study can reach a broader scope on this count. 
A. Kılıçlar - F. N. Küçükergin - E. Aysen - K. G. Küçükergin 12/1 (2020) 314-320

\section{References}

Alkan, C. (2015), Sürdürülebilir Turizm: Alaçatı destinasyonuna yönelik bir uygulama, Journal of Yaşar University, 10(40), 6692-6710.

Booking.com-1, (2019)

https://www.booking.com/content/about.tr.html?aid=331424;sid=c330a671098446261bf62c2bec254a11 (Date of access: 23.01.2019).

Booking.com-2 (2019) https://www.booking.com/content/offices.tr.html?aid=331424;sid=c330a671098446261bf62c2bec254a1 1 (Date of access: 24.01.2019)

Buhalis, D. (1999). Information technology for small and medium-sized tourism enterprises: adaptation and benefits. Information Technology \& Tourism, 2(2), 79-95.

Buhalis, D., \& Main, H. (1998). Information technology in peripheral small and medium hospitality enterprises: strategic analysis and critical factors. International Journal of contemporary hospitality management, 10(5), 198-202.

Buhalis D., Zoge M. (2007) The Strategic Impact of the Internet on the Tourism Industry. In: Sigala M., Mich L., Murphy J. (eds) Information and Communication Technologies in Tourism 2007. Springer, Vienna.

Cipriani, F. (2010). Social Media in Companies: The Online Relationship with the Market. http://www.deloitte.com/assets/DcomBrazil/Local\%20Assets/Documents/Estudos\% 20e\%20pesquisas/Midias\%20Sociais\%20_apresentacao_ingles.pdf (Date of access: 17.08.2017).

Díaz, M. R., \& F Espino, T. (2018). Determining the reliability and validity of online reputation databases for lodging: Booking.com, TripAdvisor, and HolidayCheck. Journal of Vacation Marketing, 24(3), 261-274.

Euronewstr (2018) https://tr.euronews.com/2018/12/26/tursabin-actigi-davada-bilirkisi-booking-com-unruhsat-almasina-gerek-yok (Date of access: 24.01.2019).

Fortune, (2017) http://fortune.com/2017/03/29/booking-com-turkey/ (Date of access: 11.08.2017).

Gezgin, İ. (2009). Tarih Boyunca Çeşme (Vol. 28). Şenocak.

Gülderen, K. (2007). Çeşme (İzmir) kent coğrafyası, Ege Üniversitesi, Sosyal Bilimler Enstitüsü, Yayınlanmamış Doktora tezi, İzmir.

Hürriyet, (2017) http://www.hurriyet.com.tr/booking-coma-turkiye-yasagi-40411365 (Date of access: 10.07.2017).

Independent, (2017) http://www.independent.co.uk/travel/news-and-advice/bookingcom-turkey-pricelinehotels-court-istanbul-ankara-ban-competition-authority-a7658251.html (Date of access: 17.07.2017).

İndigo Dergisi, (2017) https://indigodergisi.com/2017/03/booking-erisim-engeli/ (Date of access: 10.07.2017).

İzmir İl Kültür Turizm Müdürlüğü-1, (2017) http://www.izmirkulturturizm.gov.tr/TR,77198/yatirim-belgelikonaklama-tesis-listesi.html (Date of access: 17.08.2017).

İzmir İl Kültür Turizm Müdürlüğü-2, (2017) http://www.izmirkulturturizm.gov.tr/TR,156175/isletme-belgelikonaklama-tesis-listesi.html (Date of access: 17.08.2017).

Karaçöl, A., \& Tunçoku, S. S. (2016). Geçmişteki Su Kültürünün Sembolleri: İzmir-Çeşme'de Mevcut ve Kayip Osmanli Dönemi Çeşmeleri. Kültür Envanteri, 12(1).

Kotler, P., Bowen, J., and Makens, J. (2003). Marketing for Hospitality and Tourism(3rd edition). New Jersey: Prentice-Hall.

Muñoz, T. G., \& Amaral, T. P. (2009). Modeling the key determinants of online shopping in Spain. Retrieved from SSRN 1363999 https://papers.ssrn.com/sol3/papers.cfm?abstract_id=1363999

Oliver, R. L. (1997). Satisfaction: A behavioural perspective on the consumer. New York: Irwin/McGraw-Hill. 
A. Kılıçlar - F. N. Küçükergin - E. Aysen - K. G. Küçükergin 12/1 (2020) 314-320

Porter, M. E. (1979). The structure within industries and companies' performance. Review of economics and statistics, 61(2), 214-227.

Porter, M. (1980). E.(1980). Competitive strategy, 61-78.

Rehman, O., Liu, X., Rauf, A., and Slama, M. B. (2019). Internet tradition and tourism development: A causality analysis of BRI listed economies. Tourism Economics, 1-32.

Sabah (2018). https://www.sabah.com.tr/ekonomi/2018/12/26/bookingcom-ile-ilgili-haksiz-rekabetdavasinda-onemli-gelisme (Date of access: 24.01.2019).

Sarı, Y. (2003). Bölgesel Düzeyde Hazırlanan Web Sitelerinin Turizm Talebi Üzerine Etkisinin Araştırılması: Muğla Bölgesinde Bir Uygulama. Basılmamış Doktora Tezi, Muğla.

Schiffman, G., Kanuk, L. L., and Wisenblit, J. (2010). Consumer Behavior (10 ${ }^{\text {th }}$ Edition-Global Edition). New Jersey: Pearson.

Sputniknews, (2017) https://tr.sputniknews.com/turkiye/201703301027873566-btk-baskani-sayan-bookingengel-yok-rekabetle-ilgili-durumlarda-site-kapatilmaz/ (Date of access: 11.08.2017).

Tekin Bilbil, E. (2019). Platform coopetition in the tourism industry: conflicts and tensions caused by the closure of Booking. com in Turkey. Current Issues in Tourism, 22(13), 1617-1637.

Turizm Güncel, (2017) http://www.turizmguncel.com/haber/bookingcom-yasagina-iliskin-3-aciklama-h31123.html (Date of access: 10.08.2017).

Yatırım ve İşletmeler Genel Müdürlüğü, (2017) http://yigm.kulturturizm.gov.tr/TR,9858/belediye-belgelitesisler.html 